\title{
Factors in the Ecosystem of Mobile Payment Affecting its Use: From the Customers' Perspective in Taiwan
}

\section{Hsiaoping Yeh}

National Kaohsiung University of Sci.\&Tech., Department or Marketing \& Distribution Management, Taiwan, hpyeh2000@nkust.edu.tw

Received 9 February 2018; received in revised form 11 December 2018; accepted 7 January 2019

\section{Abstract}

In comparison with the rapid adoption and growth of mobile technologies worldwide, mobile payment services are being adopted at a slower pace than expected. In the literature, most studies about customers' use of mobile payment have focused mainly on the technological aspects. However, the businesses that provide mobile payment in terms of an ecosystem include various industries. This study integrated and empirically investigated the factors in multi-faceted nature of the mobile payment ecosystems, which influence customers' acceptance and actual adoption. Although technological and social elements influence customers' intention to use mobile payment for transactions, this study verified the important connection between cognition (intention to use) and behavior (actual usage). Service quality, service innovation, brand equity, switching costs, and public policy all impact the gap between intention and actual adoption of mobile payment.

Keywords: Mobile payment, Ecosystem, Innovation diffusion, Behavioral intention, Public policy 


\section{Introduction}

For centuries, the evolution of payment methods was slow and strictly controlled. Nowadays, owing to the emergence of mobile technologies, payments have become one of the innovative topics in the fields of economics, finance, technology, and retailing. The one-click or one-scan payment makes retail purchases easier and reduces the physical interaction with merchants. Mobile payment (hereafter m-payment) is thus widely considered as the next revolutionary payment method for shopping. Given the rise in the use of $m$-payment solutions introduced by various companies, a huge step in integrated financial and commerce practices enables more efficient shopping experiences, breaking through the boundaries of online and offline commerce, helping customers to make better choices, and merchants to improve their businesses.

In the payment methods, m-payment is an option replacing the current electronic and manual ones. Based on the overview, m-payment is a transaction procedure of monetary value for services or products using mobile devices [25]. This procedure includes initiation, authorization, and confirmation, all using wireless communication technologies. Hence, this definition establishes that m-payment is mainly related to the fields of technology and technology-driven services.

M-payment is operated by a multiplayer system called an m-payment ecosystem. An m-payment ecosystem involves interdependent interactions among multiple stakeholders, including communication technology, retailing, banking, and even government. The business interaction in this m-payment ecosystem represents a highly dynamic and coopetitive (i.e., co-existence of cooperation and competition) business structure in which the relationship creates mutual value for the viable stakeholders [51]. The widespread and maturing $\mathrm{m}$-payment leads for stakeholders within the m-payment ecosystem to promote innovative methods or mobile services in business networks. As a result, modeling the technology-driven influence on the adoption of $\mathrm{m}$-payment alone is insufficient to incorporate the whole scenario for the current and future development of m-payment. As [60] stressed that self-organizational and interorganizational innovative services for customer adoption of m-payment create opportunities and challenges to differentiate between the competitive edge of service suppliers.

Nevertheless, indicated by [54], customers play an important role in the demands on m-payment systems as well as in driving the practical success of $\mathrm{m}$-payment by adopting specific services. From perspectives of marketing, an $\mathrm{m}$ payment service is generated by a service process to create and add value for customers. Thus, m-payment services must be accepted by the logic of the user's attitudes and provide beneficial outcomes as compared to the alternatives. Extensive studies have investigated customer acceptance and usage of m-payment, but currently, have narrowed their studies to the viewpoint of technological innovations (see the reviews in [25]). That is, strictly technology-focused studies (e.g., [51], [59], [62]) offered limited contributions to acknowledging other causes such as marketing aspects and other actors in the m-payment ecosystem.

Other factors than just technological ones are likely to influence the development of m-payment and are the extended paths to influence customers' actual and intensive use of m-payment. Thus, as m-payment is at the stage away from the introduction phase and gets into the growth one in many countries, such as Taiwan, the objective of this study is to develop a framework describing the customers' actual behavior of using m-payment, which not only includes the factors for the diffusion of innovative technologies but also intensifies important aspects functioning in a $\mathrm{m}$-payment ecosystem in order for its competitiveness. The formers could only arise customers' use intension; yet, the latters can be expected to contribute to their actual usage. Therefore, in this study, three marketing-driven factors (service quality, service innovation, and brand equity) as well as both micro and macro levels of influence (switching cost and public policy, respectively) are conceptualized to all fill the gap between use intention and actual use of $\mathrm{m}$ payment.

\section{Literature Review and Framework Development}

At its current stage, m-payment is still identified as an innovative payment system because operations in the financial services are characterized by the extensive use of information communication technologies and innovative data transition techniques and are also important drivers of new business models regarding products and services in consumer markets [44]. Earlier studies have confirmed the importance of the technological factors in both merchants' [78] and customers' adoption of m-payment [21], [54]. In addition, since the mobile services offered and their created value are initially dependent on technical functionalities, it is of great importance, from this perspective, to understand characteristics of the technologies that influence customers' m-payment acceptance.

\subsection{M-payment Use Intention and Behavior}

The Technology Acceptance Model (TAM) [27] describes the factors that influence individual acceptance and adoption of technology. With emerging technologies providing an increasing level of social interaction, new approaches to understanding their adoption require not the only emphasis on the technical aspects but also on the social ones. In addition to individual technology acceptance factors in TAM, Diffusion of Innovation (DOI) [67] is the 
first model that represents this concept well. Studies based on innovation usage and diffusion models have shown that the perceived characteristics of innovation concepts and social impacts can have significant effects on adopters' attitudes toward the acceptance of innovative Information and Communication Technology (ICT) solutions in various economic fields [36], [64], [69].

Moreover, scholars have used the effect of network externalities to describe the benefits from a great number of users adopting one technology (e.g., [6], [68]). Similar to the critical mass effect [6], this effect would drive crossplatform networks to employ the m-payment technologies. Based on this effect, the value of one side will decrease if the other fades out. If only a limited amount of customers are using a service and also if the pool does not increase in time, the service providers would also stay out the market, and vice versa. Studies have empirically shown this effect on the m-payment market. If a great number of customers are ready to use m-payment, merchants would be likely to show great motivation to employ it. Conversely, if there are only a few banks and merchants offering mpayment services, customers would not enthusiastically adopt it for shopping [41].

Hence, although the adoption of a technology is an individual process that one undertakes from first hearing about it to finally using it, diffusion stresses a group phenomenon, which suggests how a new technology or an innovation spreads and how it is diffused over time in a social system and then becomes populated [40]. As stated by [79], the belief is that customers tend to turn to their social networks to reduce any doubts due to their uncertainty in the use of a new technology. The factors specified within the DOI, i.e., relative advantage, compatibility, complexity, trialability, and observability, clearly explain the features that affect the adoption of innovations and their diffusion. In other words, instead of persuading people to adopt a new idea, the DOI gets insights into being primarily about individuals' acceptance to use so that they can be better fits into themselves and their social circles [66]. The scholars researched about the diffusion model have recognized that the five qualities are able to determine the success of an innovation if it spreads more quickly than others [45].

According to the DOI, the more relative advantage of an innovation is perceived, the more willingness to use it based on the needs of potential users such as convenience, satisfaction, economic/economical advantages, or any improvement it could offer the users. Compatibility with users' current practices as well as their life and lifestyle means that the users would not pay effort to make adjustment or bring about any discontinuousness for the new adoption. Complexity continues the concept of ease-of-use in the TAM. Simpler new adoption makes potential users understandable than others without extra skills or learning. A new idea which is easy to let users have more chances for trials (i.e., higher trialability) indicates that users are easily to experience it as well as the less risk to the users who are considering it [84]. More observable results of adoption an innovation in surroundings (i.e., higher observability), including practical experiences from acquaintances and even social discussion within social networks, make individuals consider to adopt it. Besides, more discussion about adoption of a new practice (i.e., increase observability) not only increases its adoption population but also reduces the adoption uncertainty and concerns of the potential users [38]. As [45]'s study, these five factors explain $49 \%$ (at least) and $87 \%$ (at most) of the variation of individuals' adoption behavior.

In this study, m-payment is determined to have innovative traits that affect the likelihood of adoption by some customers, as well as by potential adopters who are motivated by others in the market and their social networks and are likely to make the adjustments needed to adopt the services. This motivation can be impacted by the services that have the technological and symbolic values that encourage acceptance and use.

\section{H1: The factors within the DOI positively influence user' m-payment adoption intention.}

H1a: The relative advantage of m-payment positively influences users' m-payment adoption intention.

H1b: The compatibility of m-payment positively influences users' m-payment adoption intention.

H1c: The complexity of m-payment negatively influences users' m-payment adoption intention.

H1d: The trialability of m-payment positively influences users' m-payment adoption intention.

H1e: The observability of m-payment positively influences users' m-payment adoption intention.

The effect of studying users' acceptance of technologies was mostly based on adoption intention. Yet, the success of the technology is not sufficient to be gauged by their usage intention but also affected by the users' actual behavior. The Theory of Reasoned Action (TRA) by [34] and the Theory of Planned Behavior (TPB) by [3] began to discuss human behavioral intention as being the immediate antecedent to behavior. TRA and TPB are considered as the most suitable theories to explore the cognitive determinants of human behavior they have determined that behavioral intention is a key predictor of behavior in a wide range of domains. It is believed that an individual's decision to actually engage in a particular action is based on the outcomes of what $\mathrm{s} /$ he expects will occur. The more motivation that the action is expected to deliver, the more likely it is that it will actually be performed.

TRA/TPB assumes that people are generally rational and make a judgment from the use of the information available to them. Fundamentally, behavioral intention is only one indication for the expectancy end [51]. Even if people see 
the outcomes of an action as tempting, they still might consider some implications of their actions before they finally decide to or not to engage in this activity. Some analyses have already indicated that people's behavioral intention only contributes to $20 \%$ to $30 \%$ of behavior in practice [8], [73]. This implies that there is a gap between behavioral intention and actual behavior. As discussed by [72], unless people are totally capable of carrying out their formed intention, there is more than sub-optimal measurement involved in discrepancies between intentions and behavior. Intervention affecting the link from intention to behavior requires investigation to strengthen the link. [4] also agreed there is intervention within the relationship between the intention and the action, and hence, suggested to researchers that TRA/TPB not only provides guidelines for describing human decisive cognition and behavior, but is also incumbent on investigation of the actual intervening factors.

The effects causing this gap as moderating variables have been studied in many frameworks (e.g., [33], [73]). This study was based on the discovery of the potential and important effects in the m-payment ecosystem that those are identified to fill the gap in which customers intend to use m-payment and actually use it; thus are to make its use spread significantly.

\section{H2: Users' M-payment adoption intention positively influences their adoption behavior.}

\subsection{Service Quality}

[25] reviewed the m-payment academic research and concluded that the there was little need for further studies on $\mathrm{m}$-payment adoption from customer perspectives and with technology acceptance models. Yet, the authors also claimed that studies in customers' m-payment adoption (based on the technology acceptance models) still remain one of the most important research topics, but unfortunately provide few new insights. Multi-level analyses, according to them, are required to obtain more insight into the m-payment ecosystem. Hence, factors, other than the technological ones in the ecosystem are essential in representing the real-world conditions of customers' actual $\mathrm{m}$ payment use.

In an m-payment network, financial institutions seek to collaborate with non-financial providers for payment services, such as Taiwan's t-wallet+, and vice versa, such as Apple Pay. As mentioned above, the actors in the m-payment ecosystem are in a co-opetitive relationship in order to provide leading services to attract customer's adoption for their shopping. Moreover, as mentioned, the factors leading to customers' actual use after their attraction to a certain $\mathrm{m}$-payment system were those that the provided usage that is outstanding and different from others. When customers are aware of the technological and social values of m-payment that affect them, and proceed to accept and intend to use the services, the marketing aspects affecting their behavior are of great importance for developing their actual use [70]. Therefore, the assumption of this study is that there are four factors: service quality, service innovation, switching costs from other payment methods they used to use or from the m-payment that they are currently using, and the brand equity of the m-payment service providers. These four factors are market-oriented factors from customer perspectives that would impact customers' actual m-payment adoption after their intention emerges. In addition, it is also assumed that public policy is an effective factor influencing customers' m-payment adoption since there are many public policies involved for society welfare for the m-payment engagement.

Service quality has always been one of the important issues in marketing and is considered as the vigorous element for success of businesses in a competitive environment. Generally, service quality can be considered to be how well the service performance has met customers' expectations. Service quality is believed to be a strong predictor to differentiate performance between different products and certainly between its effects on customer behavior. The services, along with the value of the m-payment process, can be extended to include telecommunication, technology, finance, financial technology, and commerce. Shareholders within the m-payment ecosystem need to be aware of all the aspects of these services because these services are not only about technologies. Concepts of customer service and customer satisfaction to ensure regular use also have to be applied to the financial services in m-payment.

The perceived quality of ICT systems is an important behavioral aspect in the adoption of such a system [39]. Moreover, to create added value in the m-payment process, there is an obvious expectation that information collected from the m-payment users will be provided in order to fulfill the needs of them rather than only to serve the convenience contributed by the technologies [70]. For example, FinTech, short for financial technology, refers to the application of technology within the industry of financial services. It has also leveled the financial playing field for ordinary people, giving them access to services previously reserved for the wealthy or individuals of a certain economic stature. With technology and data capabilities, it is much easier and cheaper to bring investment advice to individuals, and the advice that can be geared toward a certain asset level currently so that it is available to everyone. When it comes to FinTech, the number of players and services are plentiful not just in the basic aspects of banking services, but also in new broader payment features of the integration of $m$-payments including technology usage, mobility, and retailing data with financial needs [7].

A World Economic Forum's research report in 2015 [81] articulated the developing trend of financial services, providing technology-based m-payment facilitates with automated execution, which improves the efficiency and quality of the execution through connectivity with an increasing customer base. In fact, KPMG's report in 2016 found that the step-by-step changes in quality, efficiency, and user experience are necessary, and these have been practically reflected in the achievement of the mass adoption of m-payment in China. 
H3: Service quality of m-payment positively moderates the influence of users' m-payment adoption intention on their adoption behavior.

\subsection{Service Innovation}

While service quality can be identified as the outcomes compared with customers' expectations, service innovation can be regarded as service outcomes beyond their expectations. The service innovation laggards have gradually changed since the 1990s. The earlier changes were mainly focused on the use of ICT by services activities in creative rather than standard ways [59]. Service innovations were used to be implicit in the hardware components but nowadays have been gradually expanded and implemented by service industries. That is, the emphasis on technological innovation has been somewhat moderated by recognition of the importance of the 'soft' nontechnological, new elements, and approaches to service innovations [2].

[29] described service innovation well as a new service experience or service solution consisting of a new service, a new service portfolio, or a new service process that individually or in combination defines a new way of creating value for the customers. They argued that service innovation has to consist of one or several of the following dimensions in the creation of value: new service concept, new customer interaction, new value system/business partners, new revenue model, or new organizational or technological service delivery system. In short, any idea, practice, or object that is perceived as new by an individual can be an innovation. M-payment undoubtedly has undergone numerous technological innovations with continuous technological breakthroughs at our fingertips. Although m-payment is performed with financial technologies, market orientation involves doing something new or different in response to the market environment and conditions [52]. The features of $m$-payment service innovations in market orientation must not be overlooked.

Since service innovation is increasingly regarded as a competitive weapon [5], firms are compelled to seek innovation by the market's constant hunger for better services [16]. [77] agree that service innovation conveys benefits to the added customer value by providing them with renewals. Moreover, service innovation is not only all about newness. Some scholars have identified that it also includes other issues, such as after-sales services, delivering systems, the relationships with customers [28], and customer knowledge and experience [80]. That is, service innovation is a dynamic and continuous system of information being sought or accessed as well as information processed or integrated from many resources. For example, currently, FinTech companies, either technologically or financially, pursue partnerships from viable industries to create an ecosystem that fosters the collection of vast amounts of finance, retailing, and social interaction data and also builds trusted relationships with the users. As the PWC's Global FinTech Executive Summary stated, with this partnering and big data mining across markets, services providers in the ecosystem are able to embed themselves into customers' daily life and raise the percentage of practical users with multiple products. In the process, they can raise customer loyalty, generating ever more complete customer data in reality for customized services. As a result, beyond financial services, more services can be encompassed, including transportation, medical care, entertainment, and much more. Customer acquisition of m-payment and services advancement and innovations form a feedback loop to correlate with each other.

H4: Service innovation of m-payment positively moderates the influence of users' m-payment adoption intention on their adoption behavior.

\subsection{Brand Equity}

[1] defined brand equity as a company's intangible assets and liabilities relative to a brand, which would add to or subtract from the value of its products or services. [48] stressed brand equity as customer knowledge about a brand, and is considered to be the value added to products or services. Customers' perception of brand equity helps them interpret, process, and store information about products and services from various brands. This has been empirically identified as an essential factor affecting customers' confidence in purchasing decisions [17]. Recently, researchers have investigated the significant impact of customer brand equity on their choices of traditional financial services and the financial services with innovative technologies [26], [42]

The marketing literature suggests that when customers respond to two brands with the same operational values and their awareness or image towards the one is stronger than the other, the brand with a higher level of customer-based brand equity would deliver more value to them. This added value is not about the functions of the products or services provided by merchants, but are based on the customers' association with the brand name per se [80]. Customers who possess stronger brand equity towards a brand name will be willing to pay more for it than for others with the same level of product quality, due to the attractiveness of the brand name [13]. According to [1], brand equity is also identified as a company's non-price competitive advantage. Hence, companies that successfully leverage their customer brand equity to create increased value for their products or services can differentiate their business position in a non-flexible market. In addition, studies have found that while issues of privacy, security and risks are still a hindrance, explaining the hesitation of customers to use m-payment, strong brand equity in the markets and in the customers' minds would reduce customers' perceived risk of use [25], [55]. 
Rapid technological advances cause financial services to face massive competition. If companies have integrated with coherent brand equity, they are able to differentiate their services but do not need to compete on price [15]. Furthermore, in online and mobile commerce and services, brand equity is relatively important since it offers customers an opportunity to establish a mental picture of the services and service providers and also can increase customer trust towards such an invisible purchase [15].

Pinar and Trapp [63] proposed a brand ecosystem framework for a modern branding management. Brand ecosystem, unlike Moore's business ecosystem [57] which describes a specific brand integrated with its all intermediaries such as supply chain suppliers and channels selling this brand's products and services, includes a set of activities all together contribute to a strong brand that incorporates with all the stages of value creation [64]. With potential synergy of two or more brands that share a common brand space, scholars reported that customers' perception of brand attitude about a co-branded product or composite brand name is aggregated from their attitude toward each individual brand [74] as well as customers' brand equity can be built through an ingredient branding strategy [64].

Therefore, in an m-payment system as a brand ecosystem integrated with various brands of technological, financial, and retail services, strengthening customers perceived brand equity is essential to outperform competitors and gain a larger market share.

H5: The brand equity of m-payment service providers positively moderates the influence of users' m-payment adoption intention on their adoption behavior.

\subsection{Switching Costs}

Prior to m-payment, payment by cash, check, plastic money such as credit cards and debit cards, electronic money such as PayPal and others have long been used by customers for transactions. While customers are attracted by the technical merits of m-payment or influenced by others and then intend to use it, yet, the cognitive lock-in [47] to their current payment methods may be a barrier to its actual adoption. Traditional analyses of this behavioral change have focused on switching costs (e.g., [68]). Taking switching costs for customers to shift to another payment method into account may further influence their decision to actually use m-payment.

Switching costs are regarded as the costs incurred to cease the current service and to join in the new one. They include time and money, as well as psychological, social, technological aspects, such as surplus fees, search costs, learning costs, cognitive effort, emotional costs, equipment costs, installation and start-up costs, financial risk, psychological risk, and social risk [49]. Behavioral change from the status quo is not all about defection but instead a dynamic process developed over time, base on the findings regarding switching banking services found in [35]. Interestingly to note that when customers will not definitely switch to the provider offering the lowest price if they realize the switching costs in terms of monetary cost, effort, time, uncertainty, and other reasons that outweigh the price differential between the existing one and the alternatives [14]. [24] investigated customer switching behaviors and found that, for financial services, higher switching costs will restrict customers from switching services even if their minds are completely attracted to the alternatives.

The influence of switching costs on customer behavior, particularly referring to the adoption of technologies should not be overlooked. The increasing importance of switching costs with the rise of information technologies has been emphasized by researchers due to the flourishing emergence of new forms of technology, and this has created highly competitive market conditions. Thus, the cost structure of the competing brands in terms of acquisition and transaction is worthy of attention. The e-trades and e-services make customers more disposed to change financial service providers [22] since, in a technology-driven and fast-paced environment, low switching costs in terms of mobility and self-service encourage customers to make changes [83]. Moreover, according to [49], given the userfriendly functionalities of technology-based financial services, switching costs tend to be significantly diminished with diversified data assessment.

H6: Switching costs of m-payment negatively moderate the influence of users' m-payment adoption intention on their adoption behavior.

\subsection{Public Policy}

Customer behaviors are not only the marketing issues as there are also public and political ones. Public policies, such as government actions, are generally known as the principle guides to action taken by the administrative institutions in the public sector in a manner consistent with the social welfare. Tools, such as legislation, regulation, and laws to deliver the desired policy outcomes are a given an extrinsic condition that influences customers' decision making [19]. Marketers provide for customers' specific needs but their actions are usually profit-oriented. Yet, public policies are empowered to affect the availability of products and services with the express intention of achieving certain objectives with a broad social content that markets do not provide [75]. Thus, government policies can result in the creation and elimination of products in markets that have a direct impact on consumers. Additionally, public policies should take an active and leading position to encourage and take responsibility for economic and 
environmental development [32]. In order to develop sustainable customer consumption behaviors, [76] asserted that government should play a vital role in safeguarding, stabilizing and even forcing better business practices to guard the social interests, economics, and environment through public policies.

Furthermore, studies have shown that security and trust are important pre-requisites for the adoption and use of $\mathrm{m}$ payment [21], [25]. Consumer rights become the fundamental issue for many public policy decisions and for research studies on consumer behavior as well. In order to regulate the marketing activities surrounding customers and guide them making good decisions, government policies should face the contemporary challenges of advocacy, such as establishing compulsory infrastructure and technical standards, enacting guidelines, monitoring marketing channels, and educating and informing customers [75]. Public policy has begun to exert significant pressure on businesses to act in a more environmentally friendly and concerned manner [10] on one hand and impacted customer cognitions and behaviors on the other [18]

It is no doubt that markets have limitations and may fail [81]. The purpose of public policies focuses on correcting such failures by the government forces. As stated above, people's biggest concern when adopting m-payment is invasion of their privacy. Studies on public policy issues relating to marketing and customers have been carried out in the areas of consumerism-deceptive advertising, legal restraint, product labeling, and such other issues involving consumer protection [31]. [50] have criticized the issue that the growth of money markets in the banking systems and non-bank financial intermediaries does not operate effectively regarding the problems of regulations. Again, the behavioral change that underlies public policies assumes that people rationally seek to maximize their values in terms of a tradeoff between costs and benefits. However, if people know that using m-payment has adverse consequences, they will reduce its use or refuse to use it. Indeed, as [46] argued that one cause for the slow adoption rate of $m$-payment is a lack of common standards and the inconsistency of systems. They stressed that in most of the m-payment applications, complexities exist due to the diverse interests of the stakeholders in the ecosystem, which may hinder the development of the new technology. [41] also suggested that pursuing the commonality of m-payment system-setting processes at the national and international levels is the best solution. [31] found that customer behaviors are not only influenced and changed by the markets but more effectively and efficiently by social constraint and political empowerment. Thus, governments consistently enact policies in order to attempt to influence citizens' behaviors [18] if they think that m-payment done by customers and merchants is beneficial to economical development and/or social welfare.

\section{H7: Government policies of m-payment moderate the influence of users' m-payment adoption intention on their adoption behavior.}

The framework describing the factors in the m-payment ecosystem that affect the user's intention to use it and this behavior is depicted in Figure 1.

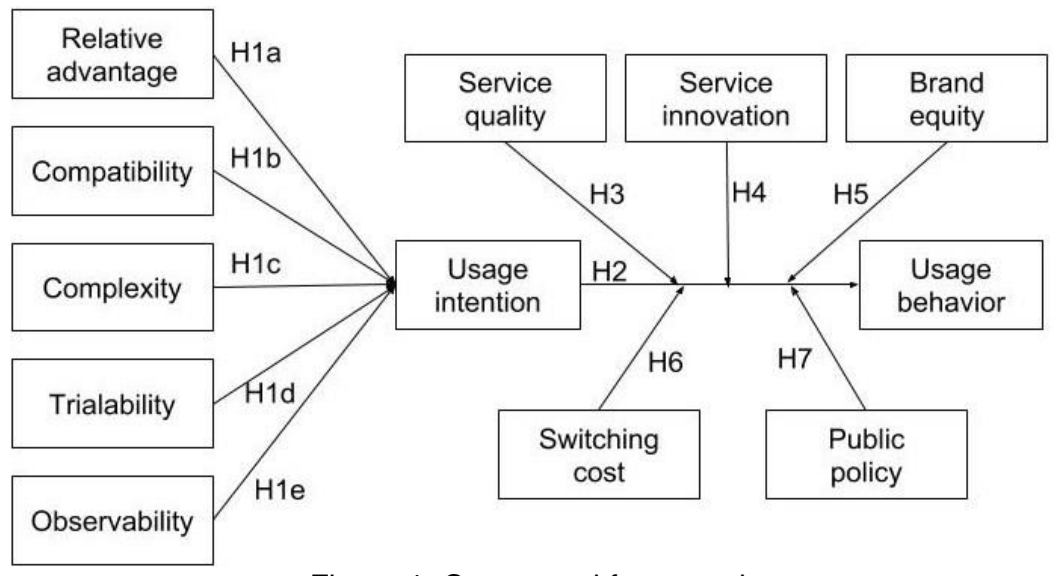

Figure 1: Conceptual framework

\section{Methodology}

To affirm the effectiveness of the proposed model, a self-designed questionnaire was used. The measurement scales (as shown in Table 1) for all constructs in the model are referred to published journal papers but modified to fit the context of m-payment. Except for the demographics, all items were measured with a 7-point Likert scale.

The questionnaire was reviewed by professionals to assess the wording and the pertinence of the questions. 115 college and graduate students were asked to participate in the pilot study. The wordings of all questions were confirmed and item analysis indicated that no questions should be deleted.

The formal data collection was conducted at several retail places that offer m-payment services in four metropolises in Taiwan such as Starbucks and convenient stores as well as MRT stations. Additionally, survey respondents must 
all, at least once, have traded with m-payment. There were 719 samples collected and 709 are valid. The demographics of the participants are summarized in Table 2.

Table 1: Measurement

\begin{tabular}{|c|c|c|}
\hline Construct & Question & Reference \\
\hline $\begin{array}{l}\text { Relative } \\
\text { advantage }\end{array}$ & $\begin{array}{l}\text { Mobile payment provides quicker access to the transactions that I } \\
\text { need to make. } \\
\text { Mobile payment provides greater flexibility. } \\
\text { Mobile payment will help me gain greater control over my finances. } \\
\text { Mobile payment will help complete all my financial transactions on } \\
\text { time. }\end{array}$ & \multirow{5}{*}[56]{} \\
\hline Compatibility & $\begin{array}{l}\text { Mobile payment is compatible with all of my financial transfer needs. } \\
\text { Mobile payment fit well with the type of transactions that I perform. } \\
\text { Using mobile payment fits well with my lifestyle. } \\
\text { My mobile phone is compatible with mobile payment. }\end{array}$ & \\
\hline Complexity & $\begin{array}{l}\text { Using mobile payment is challenging and frustrating. } \\
\text { Learning to use mobile payment is easy for me. } \\
\text { Easy to operate mobile payment is important to me. } \\
\text { I find it easy for me to be skillful at using mobile payment. }\end{array}$ & \\
\hline Trialability & $\begin{array}{l}\text { My bank provides mobile payment. } \\
\text { Mobile payment is easily available to get familiar with. } \\
\text { I do not have to expend much effort in trying to use mobile payment } \\
\text { (deleted at exploratory factor analysis EFA). } \\
\text { I do not have adequate opportunities to use mobile payment. }\end{array}$ & \\
\hline Observability & $\begin{array}{l}\text { Being seen as a user of mobile payment is good for my image. } \\
\text { People who use mobile payment are not very visible in my social } \\
\text { circle. } \\
\text { I have seen others using mobile payment. } \\
\text { I do not know anyone who uses mobile payment. }\end{array}$ & \\
\hline $\begin{array}{l}\text { Usage } \\
\text { intention }\end{array}$ & $\begin{array}{l}\text { I intend to use mobile payment. } \\
\text { I expect to use mobile payment in the future. } \\
\text { If I have chances to use mobile payment, I want to use it as much as } \\
\text { possible. }\end{array}$ & {$[61]$} \\
\hline $\begin{array}{l}\text { Service } \\
\text { quality }\end{array}$ & $\begin{array}{l}\text { The related services based on my use of mobile payment assist me to } \\
\text { achieve my financial goals. } \\
\text { The related services based on my use of mobile payment perform well } \\
\text { to protect my privacy (deleted at EFA). } \\
\text { The related services based on my use of mobile payment fulfill my } \\
\text { best interests at heart. } \\
\text { The related services based on my use of mobile payment are } \\
\text { accurate. } \\
\text { The related services based on my use of mobile payment are reliable. } \\
\text { The related services based on my use of mobile payment are } \\
\text { promising. } \\
\text { The related services based on my use of mobile payment are easily } \\
\text { accessible (deleted at EFA). }\end{array}$ & [9], [71] \\
\hline $\begin{array}{l}\text { Service } \\
\text { innovation }\end{array}$ & $\begin{array}{l}\text { The related services based on my use of mobile payment can provide } \\
\text { me new services from time to time. } \\
\text { The related services based on my use of mobile payment can capture } \\
\text { my usage behavior. } \\
\text { The related services based on my use of mobile payment can capture } \\
\text { my behavioral changes. } \\
\text { The related services based on my use of mobile payment can provide } \\
\text { me more services beyond I expect. }\end{array}$ & {$[37]$} \\
\hline $\begin{array}{l}\text { Switching } \\
\text { costs }\end{array}$ & $\begin{array}{l}\text { Compared to my other payment methods, I take a lot of time and effort } \\
\text { to use mobile payment. } \\
\text { Compared to my other payment methods, I am not sure whether using } \\
\text { mobile payment would acquire better services. } \\
\text { Compared to my other payment methods, I think the risk is higher if I } \\
\text { use mobile payment. } \\
\text { Compared to my other payment methods, I think I would have more } \\
\text { monetary losses to use mobile payment (deleted at the reliability test). }\end{array}$ & [20] \\
\hline
\end{tabular}




\begin{tabular}{|c|c|c|}
\hline Brand equity & $\begin{array}{l}\text { It makes sense to use the current mobile payment instead of any other } \\
\text { platforms and incorporated banks, even if they are the same. } \\
\text { Even if another mobile payment platform and the incorporated bank } \\
\text { have same features as the one I am using, I would prefer to use the } \\
\text { current one. } \\
\text { If there is another mobile payment platform and incorporated bank as } \\
\text { good as the one I am using, I prefer to use the current ones (deleted at } \\
\text { EFA). } \\
\text { If another mobile payment platform and the incorporated bank are not } \\
\text { different from the ones I am using in any way, it seems smarter to use } \\
\text { the current ones. }\end{array}$ & [81] \\
\hline Public policy & $\begin{array}{l}\text { Overall, I am satisfied with the government policies regarding mobile } \\
\text { payment. } \\
\text { Overall, I think the government policies regarding mobile payment are } \\
\text { effective to the development of mobile payment in Taiwan. } \\
\text { Overall, I think the government policies regarding mobile payment are } \\
\text { efficacious to the development of mobile payment in Taiwan. } \\
\text { Overall, I think the government policies regarding mobile payment are } \\
\text { worthwhile. } \\
\text { Overall, I think the government policies regarding mobile payment are } \\
\text { considerable to Taiwanese well-being. }\end{array}$ & [23], [30] \\
\hline $\begin{array}{l}\text { Usage } \\
\text { behavior }\end{array}$ & $\begin{array}{l}\text { Times of use (percentage to all available mobile payment) } \\
\text { Times of use (percentage to all payments) } \\
\text { Money amount (percentage to all available mobile payment) } \\
\text { Money amount (percentage to all payments) }\end{array}$ & [17] \\
\hline
\end{tabular}

Table 2: Demographics of survey participants

\begin{tabular}{|l|l|l|l|l|l|}
\hline Gender & \multicolumn{2}{l|}{ Age } & Education & \\
\hline Female & $42 \%$ & $18 \sim 22$ & $8 \%$ & High school & $6 \%$ \\
\hline Male & $58 \%$ & $22 \sim 29$ & $36 \%$ & College & $42 \%$ \\
\hline & & $30 \sim 40$ & $44 \%$ & Post-graduate & $52 \%$ \\
\hline & & $50+$ & $12 \%$ & & \\
\hline
\end{tabular}

\section{Analytical Results}

For the measurement appropriateness, first, an exploratory factor analysis (EFA) was performed. The Kaiser-MeyerOlkin (KMO) value is 0.91 and it passes the Barlett's test with $p$-value 0.00 , indicating that the results of the EFA are adequate. The factor loadings of all remaining indicators to their own constructs are greater than 0.59 and the cross loadings are smaller than 0.40 , which supports the construct validity of the questionnaire (in Table 3 ). The reliabilities of all constructs in terms of Cronbach's alpha are all greater than 0.8 (also shown in Table 3) and confirm the reliability of the measurement for further analyses.

Table 3: Validity and reliability of the measurement

\begin{tabular}{|l|l|l|l|l|}
\hline Construct & Factor loading (from EFA) & Cronbach's $\alpha$ & CR & AVE \\
\hline Relative advantage & $0.72 ~ 0.82$ & 0.91 & 0.82 & 0.62 \\
\hline Compatibility & $0.61 \sim 0.89$ & 0.86 & 0.86 & 0.62 \\
\hline Complexity & $0.63 \sim 0.79$ & 0.88 & 0.87 & 0.77 \\
\hline Trialability & $0.70 \sim 0.88$ & 0.84 & 0.86 & 0.65 \\
\hline Observability & $0.65 \sim 0.80$ & 0.83 & 0.87 & 0.61 \\
\hline Usage intention & $0.69 \sim 0.90$ & 0.92 & 0.81 & 0.59 \\
\hline Service quality & $0.72 \sim 0.88$ & 0.90 & 0.87 & 0.60 \\
\hline Service innovation & $0.59 \sim 0.78$ & 0.82 & 0.89 & 0.69 \\
\hline Switching costs & $0.63 \sim 0.81$ & 0.89 & 0.88 & 0.71 \\
\hline Brand equity & $0.74 \sim 0.83$ & 0.83 & 0.84 & 0.75 \\
\hline Public policy & $0.61 \sim 0.77$ & 0.83 & 0.85 & 0.65 \\
\hline Usage behavior & $0.71 \sim 0.89$ & 0.81 & 0.84 & 0.66 \\
\hline
\end{tabular}

A confirmatory factor analysis (CFA) was adopted to further affirm the convergence and discrimination among the measuring constructs. First, some indices of model fits (in Table 5) show the appropriateness of the measurement scales. Also, shown in Table 3, all composite reliabilities (CR) are greater than the 0.7 cut-off point and all values of average variance extracted (AVE) are greater than the critical value of 0.5 . Moreover, for each construct, the CR is greater than its AVE. Lastly, as shown in Table 4, the square root of AVE of each construct is greater than its 
correlation with others, which indicates that each construct relates more strongly to its own than to others. All the tests confirm that the measurement scales for this study are valid and reliable.

Table 4: Construct discrimination

\begin{tabular}{|l|l|l|l|l|l|l|l|l|l|l|l|l|}
\hline & 1 & 2 & 3 & 4 & 5 & 6 & 7 & 8 & 9 & 10 & 11 & 12 \\
\hline Relative advantage & 0.79 & & & & & & & & & & & \\
\hline Compatibility & 0.23 & 0.79 & & & & & & & & & & \\
\hline Complexity & 0.15 & 0.29 & 0.88 & & & & & & & & & \\
\hline Trialability & 0.20 & 0.31 & 0.23 & 0.81 & & & & & & & & \\
\hline Observability & 0.19 & 0.11 & 0.22 & 0.27 & 0.78 & & & & & & & \\
\hline Usage intention & 0.45 & 0.43 & 0.45 & 0.51 & 0.53 & 0.77 & & & & & & \\
\hline Service quality & 0.24 & 0.13 & 0.12 & 0.11 & 0.22 & 0.11 & 0.77 & & & & & \\
\hline Service innovation & 0.32 & 0.28 & 0.16 & 0.14 & 0.13 & 0.22 & 0.33 & 0.83 & & & & \\
\hline Switching costs & 0.21 & 0.21 & 0.17 & 0.17 & 0.13 & 0.18 & 0.13 & 0.16 & 0.84 & & & \\
\hline Brand equity & 0.29 & 0.22 & 0.14 & 0.13 & 0.17 & 0.31 & 0.37 & 0.29 & 0.17 & 0.87 & & \\
\hline Public policy & 0.25 & 0.11 & 0.12 & 0.12 & 0.20 & 0.18 & 0.14 & 0.11 & 0.10 & 0.22 & 0.81 & \\
\hline Usage behavior & 0.24 & 0.27 & 0.31 & 0.41 & 0.44 & 0.59 & 0.45 & 0.31 & 0.33 & 0.52 & 0.12 & 0.81 \\
\hline
\end{tabular}

Note: The diagonals are the square roots of AVE.

Table 5: Model fits of the conceptual model

\begin{tabular}{|l|l|l|l|}
\hline Fit index & Criterion & CFA & Conceptual model w/o moderators \\
\hline normed $\chi^{2}$ & $1<\mathrm{NC}<5$ & 2.83 & 2.27 \\
\hline GFI & $>0.9$ & 0.91 & 0.94 \\
\hline AGFI & $>0.8$ & 0.88 & 0.89 \\
\hline CFI & $>0.9$ & 0.92 & 0.92 \\
\hline RMSEA & $<0.08$ & 0.05 & 0.05 \\
\hline SRMR & $<0.1$ & 0.07 & 0.05 \\
\hline NFI & $>0.95$ & 0.96 & 0.97 \\
\hline TLI & $>0.9$ & 0.93 & 0.92 \\
\hline
\end{tabular}

The SEM analysis, with AMOS20, to test the conceptual framework without all moderators included, is depicted in Figure 2. The model fits, listed in Table 5, validate the proposed framework. All path coefficients in the framework are standardized. Therefore, the hypotheses $\mathrm{H} 1$ through $\mathrm{H} 6$ in this study are all significantly accepted at a confidence level of $95 \%$.

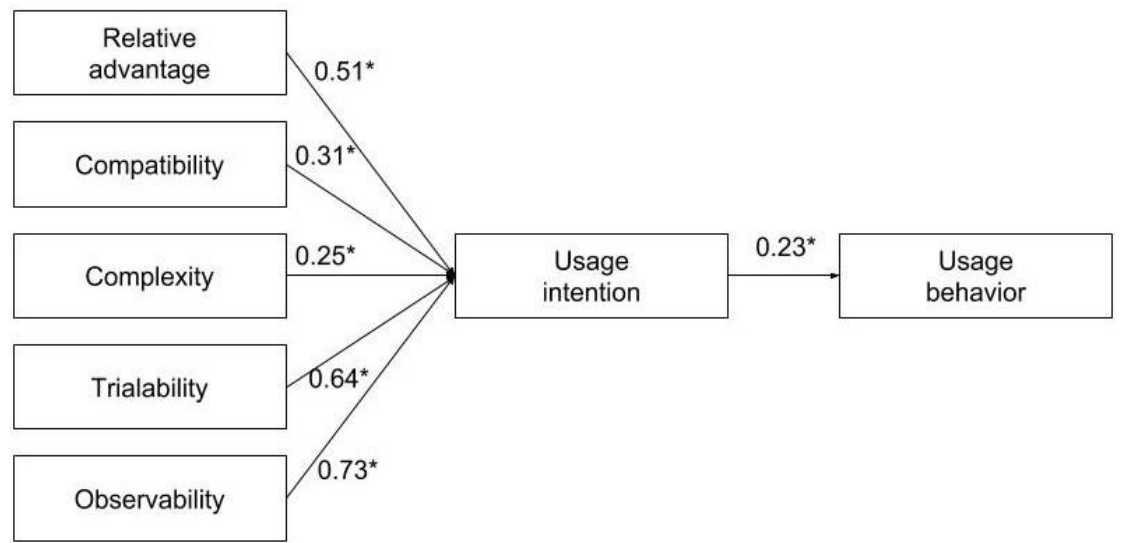

Figure 2: Path analysis

Chi-square difference tests were conducted to examine the moderating influences of service quality, service innovation, brand equity, switching costs, and public policy that affect the causal relationship between the usage intention and usage behavior of m-payment. The significance from the test indicates that the effectiveness of a causal relationship is different between higher and lower levels, classified by clustering in SPSS, of the moderator. As shown in Table 6, the moderators are all significantly effective on the causal relationship between the intention to use m-payment and usage behavior. In other words, if customers find that m-payment is attractive, they intend to use it and perhaps some actually start to use it. When they further notice that using m-payment can acquire a higher level of service quality and/or innovative services, they will adopt m-payment intensively for their shopping. Additionally, if customers perceive higher brand equity for the brands offering the services of technologies, banking services, and/or retailing, they would actually use this payment method intensively. Also, if the switching costs from their current payment methods to m-payment are too high, they would tend to use m-payment less or even not a bit. 
Lastly, for the effect of government policy, if the policy regarding m-payment is favorable for customers, it would be practically reflected in their actual adoption.

Table 6: Effectiveness of moderators

\begin{tabular}{|c|c|c|c|c|c|c|c|c|}
\hline Model & Moderator & $\chi^{2}$ & $d f$ & $\Delta \chi^{2}$ & $p$ & \multicolumn{3}{|c|}{$\begin{array}{l}\text { Regression weight of } \\
\text { intention } \rightarrow \text { behavior }\end{array}$} \\
\hline Default & & 1977.43 & 592 & & & High & Low & $\Delta$ \\
\hline \multirow{5}{*}{ Moderator } & Service quality & 1982.60 & \multirow{5}{*}{593} & $5.17^{*}$ & 0.02 & 0.47 & 0.20 & \begin{tabular}{|l|} 
\\
\end{tabular} \\
\hline & Service innovation & 1982.03 & & $4.60^{*}$ & 0.03 & 0.31 & 0.21 & 0.10 \\
\hline & Brand equity & 1994.64 & & $17.21^{*}$ & 0.00 & 0.53 & 0.22 & 0.31 \\
\hline & \begin{tabular}{|l|} 
Switching costs \\
\end{tabular} & 1986.86 & & $9.43^{*}$ & 0.00 & 0.18 & 0.65 & -0.47 \\
\hline & Public policy & 1981.61 & & $4.18^{*}$ & 0.04 & 0.41 & 0.21 & 0.20 \\
\hline
\end{tabular}

Note: all regression weights are significantly effective at a confidence level of $95 \%$

Although all moderators are significantly effective in influencing the intention to use on actual behavior, there is a distinction among the moderators in their level of effectiveness. The effectiveness of switching costs from other payment methods to m-payment impacts most on customers' actual usage. The findings indicate that in the current $\mathrm{m}$-payment market, service innovation is relatively less important for customers' use behavior.

\section{Discussion and Implications}

M-payment development differs in different countries. For example, in the US, m-payment services are provided by large retailers, such as Starbucks, which allows people to get used to them and then to influence others to start to use them. In China, with loose regulations and unique bank services, i.e., the People's Bank of China, m-payment nowadays has become a major method in retail markets and even in peer-to-peer (P2P) money transfers. The common method of m-payment in Taiwanese retail markets is prepaid or topping-ups. In 2015, Taiwan's Payment Processing Institutions Act was intended to increase the rate from $26 \%$ of electronic payment to $52 \%$ of $\mathrm{m}$-payment in five years. However, since there were too many restrictions and requirements for extra new instruments for the users, there were not many banks and merchants providing m-payment services. The population of m-payment users in Taiwan is not growing as expected. Hence, the barriers of the Act hold back the growth of m-payment in Taiwan. In 2016, the Taiwanese government finally broke the conservation. With its policy deregulation on the thirdparty payment, the $\mathrm{m}$-payment system and service providers both from the domestic and international providers will (or might) be ready for a fierce battle for this, so called 'virgin m-payment market' in Taiwan.

Anchoring the theory of $\mathrm{DOI}$ is suitable to predict customers' usage intention toward m-payment. While investigating individual intention to accept and use technologies, studies have usually adopted TAM, DOI/Innovation Diffusion Theory (IDT), and Unified Theory of Acceptance \& Use of Technology (UTAUT). Although TAM reveals the existence of external variables that can affect an individual's acceptance and use of a technology, it mainly focuses on the merits of the technologies. In addition to the factors that impact the adoption of a technology, DOI/IDT and UTAUT identify other factors, such as social impacts on an individual's cognition and behavior toward technologies. That is, although the adoption of a technology is an individual procedure that one undertakes after first hearing about an object and continuing until one finally uses it, diffusion indicates a group phenomenon, which suggests how an innovation spreads and how a technology with innovation spreads. The adoption of the technology would be diffused and widely adopted over time among users in a social system [40]. At the current level of development of m-payment, the financial and technological services have innovative traits that affect their likelihood to be adopted by others as well as by potential adopters who are motivated by others in their social networks and likely to make the adjustments needed to use them [40]. This motivation, which was measured by users' tangible and demonstrable results of their communicability, and the visibility of other users in this study, can be impacted by the technological and symbolic values that encourage acceptance and intention to use.

Based on Market Intelligence \& Consulting Institute's report in 2016, 80.2\% of Taiwanese people are willing to use m-payment but only $24.4 \%$ of them actually use it for their shopping. The two payment methods they use most are credit cards $(77.1 \%)$ and cash $(60.1 \%)$. This study found that customers' cognition towards m-payment in terms of intention to use is in line with the technological aspects and social influence of $m$-payment. New technology, such as m-payment, has to reach a certain level of diffusion and the market can, therefore, reach a certain level of maturity. However, merchants hold back in investing in m-payment systems to see customers' actual behavior. Alternatively, customers also wait and see the availability and benefits of using $\mathrm{m}$-payment. This chicken-and-egg conundrum can be solved by the power of social influence and by strengthening the expected and value-added services provided by the merchants as well as the support from the government. Thus, the market must have a sufficient level of capabilities, and companies in the m-payment ecosystem must make the requisite effort and investment to push it forward and to actually connect with customers.

In search of literature, most of the researches, even recently were still limited in the technical effects of technology acceptance models incorporated with security and privacy issues. The major contribution of this study is not mainly focused on the technology acceptance and diffusion of m-payment but many marketing attribution and the role of 
public policy influencing the actual use of m-payment. That is, other than the technical merits that only examining using intention, the powerful ignition for people's actual behavior should be the accountabilities of all players in a $\mathrm{m}$ payment ecosystem. This study investigated a few of important indicators in marketing as well as the impact of government policy. The author claims that this framework promotes the understanding of the usage behavior of $m$ payment by customers and contributes to the financial services and $m$-payment technology literature. Therefore, based on the framework, the following sections provide managerial implications for banks, merchants, technology developers, and governments to encourage customers use m-payments and services intensively.

\subsection{Service Quality and Innovation}

It is obvious that mobile channels offer enormous opportunities to increase customer experience. If $m$-payment is just about mobility for transactions, failure is inevitable. [41] suggested that based on the business value disciplines, if companies focus on the achievement of leading in technological and operational excellence in m-payment, costs of hardware investment may not be applicable to many retailers and banks. Yet, the soft endeavor to enhance customer satisfaction and even intimacy through understanding customers' needs can be the efficient and effective solution for customers in their adoption of m-payment.

The quality of offered solutions (e.g., recommendations, customization improving steadily over time) relies heavily on interaction with and the learning processes of customers. Data analytical capabilities are essential to the modification of and innovation in the services. To better understanding customer needs and behavior, cultivating a large database is necessary and can be achieved by constantly sending messages to obtain feedback of real-time customer status. Accordingly, incentives and promotions can motivate customers' consent to allow an organization to collect their data.

In addition to factual quality, offering user-generated content with a certain level of social-proximity is also important to satisfy customer interests [53]. For example, a recommendation mechanism collects customer consumption data, discovers similarities or features in the proximity of customers, and presents the findings to other customers with analogy. Furthermore, the affective quality of information can also be enhanced by offering media richness, i.e., providing multiple forms of introductions about products and services such images, audio, or video.

New data sources are emerging with evolving information technologies. M-payment not only supports the brick-andmortar trades but is also applicable to online and social commerce. With the wider range of market channels, ecommerce, m-commerce, and social networks bring digital convergence of the whole spectrum of customer behaviors. Additionally, banking and other financial data can also be incorporated into the retailing services. Notably, there is an increase in the use of self-service technologies, which diminishes the chances of direct employee assistance and personal contacts, and customers' quality expectations rely more on the technologies and interacted information. Novel technologies, such as eye-tracking and beacons, effectively enable the integration of online and offline data.

Even though IT-enabled financial innovations have been discussed for years, the pace of its growth in markets in some important applications of financial services seems to be slow. To make the Fintech development and applications successful, it is most important that customer disbelief of privacy protection should be conquered. Regulators of organizations and governments have to build firewalls to diminish this disbelief.

\subsection{Switching Costs}

Users of m-payment and other payment methods would not consider changing services if the new services offer no convincing benefits to compensate the perceived losses or better services. Therefore, providing quality and innovative services can also decrease switching costs of using $\mathrm{m}$-payment. Customers experiencing a higher level of service quality and innovation from using $\mathrm{m}$-payment can be encouraged to switch to the intensive use of $\mathrm{m}$-payment.

When customers have less understanding of the information to make a comparison among alternatives, they tend to hesitate to make changes. This suggests that all providers of $\mathrm{m}$-payment increase information transparency, which would lower switching costs from one m-payment method to another or from other payment methods to m-payment.

Businesses are not the only ones who need to understand the effects of switching costs, but also governments, acting as regulators, have to be aware of switching costs. In order to promote economic transition and advances, policy makers can offer incentives for the stakeholders in m-payment to lower the switching costs in order to affect the market growth and performance. Most importantly, government regulators have to recognize how m-payment companies collect, handle, and use customers' data, for example, whether the data collected from the users are appropriate or too far-reaching for the sake of service improvement. Policies are required to set out the responsibilities to monitor and evaluate the process from the beginning to the end in order to ensure adherence to strict standards and privacy security. Alternatively, some customers may not realize that the detailed information collected from them makes it possible for them to receive valid services and will assist them in making better decisions as well as providing protection. Thus educational and informative activities held by government can provide and disseminate knowledge for customers so that they can understand m-payment and can help to lower the costs of switching to use m-payment. 


\subsection{Brand Equity}

Nielson reported in 2014 that marketing activities promoting a company's brand contribute $51 \%$ of the weights on brand differentiation. Most researchers have pointed to communication and interaction as the most effective gateway to level up brand equity. Consistent and reliable communication about the financial service brands, highlighted by [43], are able to drive an essential element of brand success. Mobile tools enable firms to outperform other brands more easily by delivering timely information in this competitive and bursting communication environment. Digital and mobile communication provides brands with the advantages of real-time reciprocal customer-oriented content in more targeted and creative ways [58].

Before customers decide to adopt m-payment for transactions, some decisions regarding brands have to be made. The selection includes the available platforms (i.e., Apply Pay, Samsung Pay, Alipay, and others), the connecting banks, probably the connected credit cards (such as VISA, MasterCard, and JCB), and even the retailers (e.g., Starbucks). Therefore, this study suggests that in order to increase higher top-of-mind brand identification for customers to choose the m-payment platform and system, it is important to communicate with customers through various channels both independently and cooperatively at all tiers of the $\mathrm{m}$-payment ecosystem. That is, interacting with customers in more diverse ways than ever is a reliable strategy to reinforce brand equity. By doing this, mpayment service providers can also collect more details of customers' actions and discovery of customer reactions for developing added-value services. In addition, with frequent interactions, service providers can enhance customer real-time experiences adapted to the real problems that are occurring or predicted ones before they occur. Delivering tailored services to customers is an advancemnt that drives high brand equity and improves business' reputation and hence ultimately contributes to customers' actual use of m-payment. Moreover, to work cooperatively with other tiers in the m-payment ecosystem, customer data collected from a wider spectrum of their needs, reactions, and feedbacks can feasibly be integrated. Higher brand equity of an m-payment brand may therefore be created.

\subsection{Public Policy}

In order to adapt to the rapid evolution in ICT applications and mobile services, [11] pointed out that public policies should also change continuously and dynamically. Public policies should be able to offer more room for innovations as well as the realities and stabilities of social welfare in the m-payment ecosystem. When public policies support both technical and non-technical innovations, they offer benefits to all tiers in the m-payment ecosystem. To achieve this obligation, policy makers have to consider not only the direct impact of the legislative policies but also the indirect consequences of the greater population of users and service/technology providers. Hence, surveys of marketing and customer behavior should be conducted by government regularly.

Since m-payment enables convenient and efficient payment, government can also offer m-payment for governmental payments, such as taxes, fines, electricity, and welfare donations. The Taiwanese e-Bill App integrates many governmental and non-governmental payments and the supporting technologies and momentum of these activities could eventually make physical wallets obsolete. Such endorsement by government increases the uses of the technology and encourages its use as a standard payment method for the public. However, it is important for government agencies to choose proper m-payment platforms and systems which provide a mechanism for data security.

In conclusion, for an emerging market, the government plays an important role in supporting and fostering the development of m-payment growth and prosperity. Incentives and lower installation costs motivate merchants and banks to initiate and develop m-payment as well as further innovative m-payment solutions. Also regulators must make sure that the current infrastructure can meet the requirements of m-payment systems. This will avoid the additional costs for all players in the m-payment ecosystem including customers to commit to using m-payment.

\section{Conclusions}

According to the findings, practices in various ways regarding brand management, responsibilities of policy makers, and both technological and non-technological services all influence the market growth of m-payment. Nowadays, since customers are facing emerging and improved technologies, well-performed brand management, good service quality to meet their needs, creative services beyond their expectations, broader interaction channels, and lower prices are in general necessary in this increasingly competitive m-payment market. Meanwhile, government is also an important player in the m-payment ecosystem. Efforts of policy makers are to make this system technologically integrated and financially more resilient so that it can continue to contribute to economic growth. With the cocompetitive endeavor of all participants in a m-payment ecosystem, synergies will result in a significant advancement in m-payment.

This study explores essential factors influencing customers' intention to use and actual use of m-payment from a wider spectrum of technology, social influence, marketing, and public policy. The model includes most players in the $\mathrm{m}$-payment ecosystem than the studies in the literature. Owing to the current researches regarding use of $\mathrm{m}$ - 
payment were mostly technological focus and also this focus was limitedly incorporated with users' adoption intention. As argued, the actual use would practically contribute to the growth of $m$-payment. With the rapid rate of using m-payment at the customer side, it should definitely be an incentive to enlarge the scope of m-payment services at the merchant side. This is the major contribution of this study. Thus, as the development of $m$-payment has been stepping into the growing stage from the introductory one, in Taiwan for example, the framework of this study provides insight of promoting customers' actual using m-payment. It is worthy for merchants, technology developers, banks, financial service providers, and governments to have inter- and intra-organizational communication in order to strengthen their m-payment ecosystem and increase their market share of the m-payment.

The developed model can be applied to other countries or studied for cultural comparison. Studies associated with more other customer attitudinal and behavioral reflections toward m-payment, which fill and/or shorten the gap between its adoption intention and actual uses in the economical markets (e.g., m-payment platforms, Fintech, retail value-added services), are still needed. That is, due to the time-longitude and service-latitude for m-payment development and evolution toward its maturity, there are still many marketing, managerial, technological and even governmental factors and issues influencing customer behavior. For example, when m-payment has reached a certain degree of maturity that it is used by a great deal of the population, customer loyalty will become an issue worthy of further study. Moreover, the behavior of using m-payment in this study was measured by frequency and amount of money related to m-payment uses. Since, proven in this study, government policy is one contributing factor to actually adopting m-payment, level of its attachment [12] can be accounted as an alternative scale to measure the behavioral m-payment usage. This is a limitation of this study and also another future direction to be added in m-payment literature.

\section{References}

[1] D. A. Aaker, Managing Brand Equity. New York: Free Press, 1991

[2] R. Agarwas and W. Selen, Dynamic capability building in service value networks for achieving service innovation, Decision Science, vol. 40, no. 3, pp. 431-475, 2009.

[3] I. Ajzen, From intentions to actions: A theory of planned behavior, in Action Control: From Cognition to Behavior (J. Kuhl and J. Beckmann, Eds.). Heidelberg: Springer, 1985, pp. 11-39.

[4] I. Ajzen and M. Fishbein, Factors influencing intentions and the intention-behavior relation, Human Relations, vol. 27 , no. 1, pp. 1-15, 1974 .

[5] R. K. Akamavi, A research agenda for investigation of product innovation in the financial services sector, Journal of Service Marketing, vol. 19, no. 6, pp. 359-378, 2005.

[6] D. Allen, New telecommunications services: Network externalities and critical mass, Telecommunication Policy, vol. 12, no. 3, pp. 257-271, 1988.

[7] R. Alt and T. Puschmann, The rise of customer-oriented banking: Electronic markets are paving the way for change in the financial industry, Electronic Marketing, vol. 22, no. 4, pp. 203-215, 2012.

[8] C. J. Armitage and M. Conner, Efficacy of the theory of planned behaviour: A meta-analytic review, British Journal of Social Psychology, vol. 40, no. 4, pp. 471-499, 2001.

[9] L. Bahia and J. Nantel, A reliable and valid measurement scale for the perceived service quality of banks, International Journal of Bank Marketing, vol. 18, no. 2, pp. 84-91, 2000.

[10] S. Barakat and G. Cairns, Environmental orientation and corporate strategy: On the way to corporate sustainability, in Proceedings 10th International Conference on Greening of Industry Network, Göteborg, Sweden, 2002.

[11] J. M. Bauer, Platforms, systems competition, and innovation: Reassessing the foundations of communications policy, Telecommunication Policy, vol. 38, no. 8-9, pp. 662-673, 2014.

[12] D. Belanche, L. V. Casaló and C. Orús, City attachment and use of urban services: Benefits for smart cities, Cities, vol. 50, pp. 75-81, 2016.

[13] D. C. Bello and M. B. Holbrook, Does an absence of brand equity generalize across product classes? Journal of Business Research, vol. 34, pp.125-131, 1995.

[14] N. Bendapudi and L. L. Berry, Customers' motivations for maintaining relationships with service providers, Journal of Retailing, vol. 73, no. 1, pp. 15-37, 1997.

[15] L. L. Berry, Cultivating service brand equity, Journal of Academic Marketing Science, vol. 28, no. 1, pp. 128-137, 2000.

[16] L. L. Berry, V. Shankar, J. T. Parish, S. Cadwallader, and T. Dotzel, Creating new markets through service innovation, Sloan Management Review, vol. 47, no. 2, pp. 56-63, 2006.

[17] J. Bojei and W. C. Hoo, Brand equity and current use as the new horizon for purchase intention of smartphone, International Journal of Business and Society, vol. 13, no. 1, pp. 33-48, 2012.

[18] L. Briggs, Changing Behaviour: A Public Policy Perspectives. Commonwealth of Australia, Australian Public Service Commission, 2007.

[19] P. C. Burger and A. Venkatesh, A study of public policy impact on consumer decision-making, in Advances in Consumer Research (W. L. Wilkie and A. Abor, Eds.). vol. 6, MI: Association for Consumer Research, 1979, pp. 508-513.

[20] T. A. Burnham, J. K. Frels and V Mahajan, Consumer switching costs: A typology, antecedents, and consequences, Journal of the Academy of Marketing Science, vol. 31, no. 2, pp. 109-126, 2003. 
[21] L.-D. Chen, A model of consumer acceptance of mobile payment, International Journal of Mobile Communication, vol. 6, no. 1, pp. 32-52, 2008

[22] D. S. Y. Cheng, An analysis of customer switching Internet banks in Hong Kong, Journal of Global Business Management, vol. 8, no. 2, pp. 114-125, 2012.

[23] C. Coglianese, Measuring regulatory performance: Evaluating the impact of regulation and regulatory policy, OECD, Expert Paper No 1, 2011.

[24] M. Colgate and B. Lang, Switching barriers in consumer markets: An investigation of the financial services industry, Journal of Consumer Marketing, vol. 18, no. 4/5, pp. 332-348, 2001.

[25] T. Dahlberg, J. Guo and J. Ondrus, A critical review of mobile payment research, Electronic Commerce Research and Applications, vol. 14, no. 5, pp. 265-284, 2015.

[26] D. Das, A conceptual framework to measure brand equity in Indian Banking \& financial services firms, Journal of Business Management, vol. 6, no. 3, pp. 12-18, 2012.

[27] F. D. Davis, Perceived usefulness, perceived ease of use, and user acceptance of information technology, MIS Quarterly, vol. 13, no. 3, pp. 319-340, 1989.

[28] J. P. J. de Jong and P. A. Vermeulen, Organizing successful new service development: A literature review, Management Decision, vol. 41, no. 9, pp. 844-858, 2003.

[29] P. den Hertog P. W. Aa and M. W. de Jong, Capabilities for managing service innovation: Towards a conceptual framework, Journal of Service Management, vol. 21, no. 4, 490-514, 2010.

[30] P. Dolan, R. Layard and R. Metcalfe, Measuring Subjective Well-Being for Public Policy. The Office for National Statistics, Office of Public Sector Information, Crown Copyright Licensing and Public Sector Information, UK, 2011.

[31] S. Dubuisson-Quellier, From consumerism to the empowerment of consumers: The case of consumer oriented movements in France, Sustainability, vol. 2, no. 7, pp. 1849-1868, 2010.

[32] K. Dummett, Drivers for corporate environmental responsibility, Environment, Development and Sustainability, vol. 8, no. 3, pp. 375-389, 2006

[33] B. M. Fennis, M. A. Adriaanse, W. Stroebe, and B. Pol, Bridging the intention-behavior gap: Inducing implementation intentions through persuasive appeals, Journal of Consumer Psychology, vol. 21, no. 3, pp. 302-311, 2011

[34] M. Fishbein and I. Ajzen, Belief, Attitude, Intention, and Behavior: An Introduction to Theory and Research. Reading, MA: Addison-Wesley, 1975.

[35] R. Garland-Thomson, Integrating disability, transforming feminist theory, NWSA Journal, vol. 14, no. 3, pp. 1-32, 2002.

[36] J. L. Garrett, R. Rodermund, N. Anderson, S. Berkowitz, and C. A. Robb, Adoption of mobile payment technology by consumers, family and consumer, Sciences Research Journal, vol. 42, no. 2, pp. 358-368, 2014.

[37] H. Gatignon, M. L. Tushman, W. Smith, and P. Anderson, A structural approach to assessing innovation: Construct development of innovation locus, type, and characteristics, Management Science, vol. 48, no. 9, pp. 1103-1122, 2002.

[38] U. J. Gelinas Jr. and J. L. Gogan, Internet payment mechanisms: Acceptance and control issues, in Challenges of Information Technology Management in the 21st Century (M. Khosrowpour, Ed.). Hershey, PA: Idea Group Publishing, 2000, pp. 24-33.

[39] D. Gilbert, P. Balestrini and D. Littleboy, Barriers and benefits in the adoption of egovernment, International Journal of Public Sector Management, vol. 14, no. 4, pp. 286-301, 2004.

[40] T. Greenhalgh, G. Robert, F. Macfarlane, P. Bate, and Q. Kyriakidou, Diffusion of innovations in service organizations: Systematic review and recommendations, The Milbank Quarterly, vol. 82, no. 4, pp. 581-629, 2004.

[41] J. Guo and H. Bouwman, An analytical frame work for an m-payment ecosystem: A merchants' perspective, Telecommunication Policy, vol. 40, no. 2-3, pp. 147-167, 2016.

[42] Z. Gürhan-Canli, C. Hayran and G. Sarial-Abi, Customer-based brand equity in a technologically fast-paced, connected, and constrained environment, Academy of Marketing Science Review, vol. 6, no. 1, pp. 23-32, 2016

[43] M. J. Hatch and M. Schultz, Are the strategic stars aligned for your corporate Brand? Harvard Business Review, vol. 79 , no. 2, pp. 128-134, 2001.

[44] E. D. Hatzakis, S. K. Nair and M. L. Pinedo, Operations in financial services: An overview, Production and Operations Management, vol. 19, no. 6, pp. 633-664, 2010

[45] D. H. Henard and D. M. Szymanski, Why some new products are more successful than others, Journal of Marketing Research, vol. 38, no. 3, pp. 362-375, 2001.

[46] S. Kadhiwal and A. U. S. Zulfiquar, Analysis of m-payment security measures and different standards, Computer Fraud \& Security, vol. 2, no. 6, pp. 12-16, 2007.

[47] M. L. Katz and C. Shapiro, Product introduction with network externalities, The Journal of Industrial Economics, vol. 40, no. 1, pp. 55-83, 1992.

[48] K. L. Keller, Conceptualizing, measuring, and managing customer-based brand equity, Journal of Marketing, vol. 57, no. 1 , pp. 1-22, 1993.

[49] D. Kundisch and W. Steck, Trust and switching costs in the financial services industry, in Proceedings The 6th WSEAS International Multiconference of Circuits, Systems, Communication and Computers, Germany, 2002, pp. 1-6.

[50] J. Liu, R. J. Kauffman and D. Ma, Competition, cooperation, and regulation: Understanding the evolution of the mobile payments technology ecosystem, Electronic Commerce Research and Applications, vol. 14, no. 5, pp. 372-391, 2015. 
[51] G. F. Loewenstein, E. U. Weber, C. K. Hsee, and N. Welch, Risk as feelings, Psychology Bulletin, vol. 127, pp. 267-286, 2001

[52] B. Lukas and O. C. Ferrell, The effect of market orientation on product innovation, Journal of Academic Marketing Science, vol. 28, no. 2, pp. 239-247, 2000.

[53] R. Mahnke, A. Benlian and T. Hess, A grounded theory of online shopping flow, I International Journal of Electronic Commerce, vol. 19, no. 3, pp. 54-89, 2015

[54] N. Mallat, M. Rossi, V. K. Tuunainen, and A. Öörni, The impact of use context on mobile services acceptance: The case of mobile ticketing, Information \& Management, vol. 46, no. 3, pp. 190-195, 2009.

[55] V. W. Mitchell and M. Greatorex, Risk perception and reduction in the purchase of consumer services, The Service Industrial Journal, vol. 13, no. 4, pp. 179-200, 1993.

[56] G. C. Moore and I. Benbasat, Development of an instrument to measure the perceptions of adopting an information technology innovation, Information Systems Research, vol. 2, no. 3, pp. 192-222, 1991.

[57] J. F. Moore, The Death of Competition: Leadership and Strategy in the Age of Business Ecosystem. New York: Harper Business, 1996.

[58] A. Morgan-Thomas and C. Veloutsou, Beyond technology acceptance: Brand relationships and online brand experience, Journal of Business Research, vol. 66, no. 1, pp. 21-27, 2013.

[59] Y. P. Mun, H. Khalid and D. Nadarajah, Millennials' perception on mobile payment services in Malaysia, Procedia Computer Science, vol. 124, pp. 397-404, 2017.

[60] P. Ozcan and F. M. Santos, The market that never was: Turf wars and failed alliances in mobile payments, Strategic Management Journal, vol. 36, no. 10, pp. 1486-1512, 2014.

[61] P. A. Pavlou, Consumer acceptance of electronic commerce: Integrating trust and risk with the technology acceptance model, International Journal of Electronic Commerce, vol. 7, no. 3, pp. 69-103, 2003.

[62] C. S. Phonthanukitithaworn, C. Sellitto and W. L. Fong, An investigation of mobile payment (m-payment) services in Thailand, Asia-Pacific Journal of Business Administration, vol. 8, no. 1, pp. 37-54, 2016.

[63] M. Pinar and P. Trapp, Creating competitive advantage through ingredient branding and brand ecosystem: The case of Turkish cotton and textiles, Journal of International Food \& Agribusiness Marketing, vol. 20, no. 1, pp. 29-56, 2008.

[64] M. Pinar, P. Trapp, T. Girard, and T. E. Boyt, Utilizing the brand ecosystem framework in designing branding strategies for higher education, International Journal of Educational Management, vol. 25, no. 7, pp. 724-739, 2011.

[65] C. R. Plouffe, J. S. Hulland, and M. Vandenbosch, Research report: richness versus parsimony in modeling technology adoption decisions: Understanding merchant adoption of a smart cardbased payment system, Information System Research, vol. 12, no. 2, pp. 208-222, 2001.

[66] L. Robinson, Changeology: How to Enable Groups, Communities and Societies to Do Things They've Never Done Before. Cambridge: UIT Cambridge Ltd., 2012.

[67] E. M. Rogers, Diffusion of Innovations. New York: The Free Press, 1962.

[68] C. Shapiro and H. R. Varian, Information Rules: A Strategic Guide to Network Economics. Boston: Harvard Business School Press, 1999.

[69] M. Shareef, N. Archer, V. Kumar and U. Kumar, Developing fundamental capabilities for successful egovernment implementation, International Journal of Public Policy, vol. 6, no. 3, pp. 318-335.

[70] M. A. Shareef, U. Kumar and V. Kumar, Role of different electronic-commerce (EC) quality factors on purchase decision: A developing country perspective, Journal of Electronic Commerce Research, vol. 9, no. 2, pp. 92-113, 2008.

[71] N. Sharma and P.G. Patterson, The impact of communication effectiveness and service quality on relationship commitment in consumer, professional services, Journal of Services Marketing, vol. 13, no. 2, pp. 151-170, 1999.

[72] P. Sheeran, Intention-behavior relations: A conceptual and empirical review, European Review of Social Psychology, vol. 12, no. 1, pp. 1-36, 2002.

[73] P. Sheeran and S. Orbell, Do intentions predict condom use? Meta-analysis and examination of six moderator variables, British Journal of Social Psychology, vol. 37, no. 2, pp. 231-250, 1998.

[74] B. L. Simonin and J. A. Ruth, Is a company known by the company it keeps? Assessing the spillover effects of brand alliances on consumer brand attitudes, Journal of Marketing Research, vol. 35, no. 1, pp. 30-42, 1998.

[75] D. W. Stewart, Why marketers should study public policy? Journal of Public Policy \& Marketing, vol. 34, no. 1, pp. 1-3, 2015.

[76] B. C. Tan and T. C. Lau, Attitude towards the environment and green products: Consumers' perspective, Management Science and Engineering, vol. 4, no. 2, pp. 27-39, 2010.

[77] M. Toivonen and T. Tuominen, Emergence of innovations in services, The Service Industrial Journal, vol. 29, no. 7, pp. 887-902, 2009

[78] B. I. J. M. Van Der Heijden, Individual career initiatives and their influence upon professional expertise development throughout the career, Journal of Training and Development, vol. 6, no. 2, pp. 54-79, 2002.

[79] V. Venkatesh, J. Y. L. Thong and X. Xu, Consumer acceptance and use of information technology: Extending the unified theory of acceptance and use of technology, MIS Quarterly, vol. 36, no. 1, pp. 157-178, 2012.

[80] J. Weerawardena, Exploring the role of market learning capability in competitive strategy, European Journal of Marketing, vol. 37, no. 3/4, pp. 407-429, 2003.

[81] WEF. 2015, The future of financial services: How disruptive innovations are reshaping the way financial services are structured, provisioned and consumed. World Economic Forum. [Online]. Available: http://www3.weforum.org/docs/WEF The future of financial services.pdf 
[82] C. Winston, Government Failure versus Market Failure: Microeconomics Policy Research and Government Performance. Washington, DC: Brookings Institution Press, 2006.

[83] X. Zhang, Retailers' multichannel and price advertising strategies, Marketing Science, vol. 28, no. 6, pp. 10801094, 2009.

[84] M. Zolfagharian and A. K. Paswan, Customer co-production and service innovation characteristics: A conceptual argument, in Adoption of Innovation (A. Brem A. and É. Viardot, Eds,). Cham: Springer, 2015, pp. 57-73. 